\title{
The British state 'security syndrome' and Muslim diversity: challenges for liberal democracy in the age of terror
}

\author{
Stefano Bonino ${ }^{1}$
}

Published online: 4 April 2016

(C) The Author(s) 2016. This article is published with open access at Springerlink.com

\begin{abstract}
This paper explores the securitisation of British Muslims within a global context in which tensions are reignited by the threat that Islamist terrorism, and Islam more generally, are considered to pose to the West. While Western involvement in Muslim-majority countries continues to fuel the idea of a 'clash of civilisations', domestic responses to terrorism and extremism take forward its rhetoric. At the heart of 15 years of wide-ranging responses lies the state 'security syndrome'. Operating through the paradigm of risk reduction, the British state has reasserted its primary role as the distributor of security in ways that move beyond the surgical targeting of violent Islamists and their supporters and instead risk impacting on Muslims qua Muslims. Counter-terrorism and anti-extremism notions and practices that conflate security risks and cultural threats signal that Great Britain is a liberal democracy that is yet to fully foster positive inter-community relations and achieve social cohesion.
\end{abstract}

Keywords Muslims · Great Britain · Security · Counter-terrorism · 9/11 · Clash of civilisations $\cdot$ Democracy

\section{Introduction}

In casting light on the nature of the ongoing securitisation of British Muslims through a series of counter-terrorism measures that have been deployed since $9 / 11$, it is important to recognise the wider and deeper political, social and cultural interconnections between Great Britain, and the West more generally, and Muslims, and Islam more generally. History and geopolitical dynamics have shaped the ideological contours of

Stefano Bonino

stefano.bonino@northumbria.ac.uk

1 Department of Social Sciences, Northumbria University, Newcastle upon Tyne NE1 8ST, UK 
a West-Islam dichotomy, from the Battle of Tours in 732 AD, when Charles Martel led a victory over the Umayyad Caliphate army and secured the defence of Europe from external forces (Hanson 2001), up to the recent military interventions in Afghanistan, Iraq and Syria as part of the Global War on Terror. In contemporary times, the global dimension of the alleged clash of civilisations between the Western world and the Muslim world has often translated into domestic cultural narratives $^{1}$ of a conflict between 'us' - the liberal British-and 'them' - the 'backward' Muslims who are believed to threaten the social and cultural fabric of Great Britain and the security of its citizens. Against this landscape, the last three British governments have responded to, and partly fed, public perceptions of a domestic cultural clash of civilisations. Operating through the paradigm of risk reduction, the British state has reasserted its primary role as the distributor of security in ways that move beyond the surgical targeting of violent Islamists $^{2}$ and their supporters and instead risk impacting on Muslims qua Muslims. This paper's main contention is that counter-terrorism and anti-extremism notions and practices that conflate security risks and cultural threats signal that Great Britain is a liberal democracy that is yet to fully foster positive inter-community relations and achieve social cohesion.

\section{Violent actions, extreme ideas and Muslim communities: security practices and discourses in contemporary Britain}

The exacerbation of the domestic tensions between Muslims and the British state and security apparatus has occurred through the deployment of a series of measures aimed at countering the real and perceived risk of terrorism and, in particular, reasserting the state's primary function in the sphere of social order and in the distribution of security. Terrorism is one of the four most serious threats, alongside state-based threats, cybercrime and the erosion of the rules-based international order, expounded in the National Security Strategy and Strategic Defence and Security Review 2015 (Home Office 2015a). Great Britain faces an ongoing threat from Islamist terrorist groups and individuals (MI5 2016). ${ }^{3}$ The bombings on London's transportation system in 2005, the bombings at Glasgow International Airport in 2007 and the murder of British soldier Lee Rigby in Woolwich in 2013 all serve to illustrate this point. In the past year alone, at least seven different Islamist terrorist plots were disrupted by law enforcement and security and intelligence services (Home Office 2015a). Between 2003 and 2011, at

\footnotetext{
${ }^{1}$ Of course, there are some countervailing narratives at play in the British cultural script, from the millionperson 'Stop the War' march in 2003, to Prime Minister David Cameron prefacing every statement he makes about Islamist terrorism with the words 'this is not about Islam'. However, with regard to this last point, one should not be naive with regard to the fact that Cameron's words may simply be a political stratagem, as he knows very well that if he did say anything remotely critical of Islam he would be strongly criticised by The Guardian, the Muslim Council of Britain and numerous other organisations that work to counter the 'us/them' dichotomy.

${ }^{2}$ Violent Islamists ideologically associated with al-Qaeda and likeminded groups can also be defined 'Salafist jihadists', that is people who "combine revolutionary Islam originating from Egypt with fundamentalist Islam as practiced in Saudi Arabia (Salafism or Wahhabism)" (Nesser 2015:6).

${ }^{3}$ Readers wishing to consult a minutely detailed historical analysis of the development and formation of Islamist terrorist circles in Great Britain should consult Raffaello Pantucci's (2015) work.
} 
least eight major foiled terrorist plots ${ }^{4}$ involved would-be perpetrators who were conspiring to murder and/or cause explosions (Herrington 2015b). It is possible to document close to a dozen Islamist-related terrorist incidents in the last 7 years stemming from one English town alone, High Wycombe, including eight arrests in relation to a plot to blow up seven transatlantic planes in 2009. In the decade after 9/11, 150 people were convicted for Islamist-related terrorism in the United Kingdom (Vidino and Brandon 2012).

The terrorist alert is high across Europe, especially after the three Islamist terrorist attacks that struck France twice, in Paris, and Denmark, in Copenhagen, in 2015, leaving a total of 150 people dead and 395 people injured. The latest terrorist attack, which killed 32 people and injured 315 others in Brussels, Belgium, in March 2016, further demonstrates that violent Islamists pose a real and serious threat to European societies. The mobilisation of Western Muslims in support of the Islamic State in the Middle East is unprecedented in size even when compared to the historical antecedents in Afghanistan in the 1980s, Bosnia and Chechnya in the 1990s and Afghanistan, Iraq and Somalia in the 2000s (Vidino 2015a). By late 2014, as many as 5,000 European-based fighters travelled to Syria and Iraq to join the ranks of the Islamic State (Europol 2015). Reportedly, 800 of these fighters travelled from the United Kingdom (Home Office 2015a). ${ }^{5}$ The decentralised structure of the Islamic State and its capacity to trigger " "individual jihad' operations by unaffiliated sympathisers in the West" (Hegghammer and Nesser 2015:27) has alarmed security agencies across the West and has warned experts of the need to consider the political, diplomatic and military responses to a potential, large-scale terrorism campaign.

The British security measures that have been put in place in the past 13 years form part of a holistic, mixed 'high policing' ${ }^{6}$ and 'low policing'7 approach (Bonino 2012) whose remit and scope are set out in a counter-terrorism strategy called CONTEST (Home Office 2011). CONTEST operates as a domestic, multiagency strategy: it evolved out of the long-standing British experience of combating Irish-related terrorism during the Northern Ireland conflict (Gearson and Rosemont 2015) and was adapted to respond to the increasingly serious threat posed by Islamist terrorism at the beginning of the twentyfirst century. CONTEST was originally developed within the Home Office in 2003 and made publicly available in 2006. It was revised in 2009 and in 2011 and is due to be further updated in 2016 "through a new National Security Council (NSC) committee on Counter-Terrorism, chaired by the Prime Minister" (Home Office 2015a:37). CONTEST's aims are fourfold: (1) to Prevent violent extremism, (2) to Prepare the country for a terrorist attack, (3) to Protect the country from a terrorist attack, and (d) to Pursue terrorists. Counter-terrorism-related regulations and provisions are set out in various pieces of legislation such as the Terrorism Act 2000, the Anti-Terrorism, Crime and

\footnotetext{
${ }^{4}$ The code names for the police operations that disrupted these terrorist plots are: Operation Crevice (2003); Operation Theseus (2005); Operation Vivace (2005); Operation Overt (2006); Operation Gamble (2007); Operation Seagram (2007); Operation Pitsford (2011); and an unnamed police operation in Exeter in 2008 (Herrington 2015b).

${ }^{5}$ In the first three quarters of 2015, in the United States around 250 fighters travelled to the Middle East to join the Islamic State and about 900 individuals were actively investigated as Islamic State sympathisers across 50 American states. Moreover, 56 individuals were arrested in 2015 alone, a record yearly figure for terrorismrelated arrests since 2001 (Vidino and Hughes 2015).

${ }^{6}$ For a full discussion on 'high policing', which is broadly defined as 'political surveillance', readers should consult the work of Jean-Paul Brodeur (1983).

${ }^{7}$ For a full discussion on 'low policing', which is broadly defined as 'law enforcement', readers can again consult the work of Jean-Paul Brodeur (1983).
} 
Security Act 2001, the Prevention of Terrorism Act 2005, the Terrorism Act 2006, the Counter-Terrorism Act 2008, the Terrorism Prevention and Investigation Measures Act 2011, the Protection of Freedoms Act 2012, the Data Retention and Investigatory Powers Act 2014 and the Counter-Terrorism and Security Act 2015.

Several measures and legislations utilised to prevent violent extremism and combat terrorism have received their fair share of public, academic and expert criticism: the Prevent strategy within CONTEST (Horne and Bestvater 2016; Richards 2012); stop and search powers that fall under Schedule 7 and the now-repealed Section 44 of the Terrorism Act 2000; and restrictions of individuals' movement, communication, work, financial activities and so on in the form of 'control orders' (Prevention of Terrorism Act 2005), which were repealed in 2011 in favour of lighter versions - that is, Terrorism Prevention and Investigation Measures (TPIMs) (Fenwick 2011a, b). Literature across the critical domain in sociology, criminology and security studies has extensively criticised the British government for the following practices: widening the net beyond terrorist groups to target Muslim communities at large (Pantazis and Pemberton 2009); stigmatising and alienating Muslims qua Muslims (Bartlett and Birdwell 2010; Choudhury and Fenwick 2011) through extensive surveillance (Thomas 2012); and, overall, fostering social cleavages (Hewitt 2008) between 'us'-the modern, liberal British inhabiting a "society 'under attack'" (Hickman et al. 2011:3) — and 'them' - the dangerous, fundamentalist Muslims.

This latter point certainly represents an analysis stretched to the extreme. However, it shows the path that security practices, building upon both legitimate concerns for the real and serious threat that Islamist terrorism poses to European Member States ${ }^{8}$ (Europol 2015) and the global, political and cultural fears of Muslims, have taken in the direction of a symbolic embodiment of a domestic cultural clash of civilisations. The value of such an analysis also demonstrates the continuum in the recycling of punitive and preventative measures in dealing with 'problem populations'. This approach originated in the 1970 s with the impetus in securitising Irish communities during the Northern Ireland conflict (Hillyard 1993) and later translated into the post9/11 emergence of a 'British Leviathan'. Stefano Bonino (2013:5) posits that the British Leviathan acquires its power from "a reinforced state sovereignty and embodies the normalisation of a 'state of permanent exception' in which the securitisation mantra penetrates the social fabrics and individual rights are superseded in favour of enhanced state authority". This mantra operates within a complex social context in which British Muslims' process of violent radicalisation escapes definitive explanations. Instead, it emerges as a consequence of multiple interconnected factors, ranging from ideology, grievance and mobilisation (Pantucci 2015) to personal vulnerabilities ${ }^{9}$ and political discontent with foreign policy (House of Commons 2012).

\footnotetext{
${ }^{8}$ In this sense, the position that counter-terrorism measures should never endanger the Schengen system and freedom of movement (Bigo et al. 2015b) should more realistically consider the opportunities that a borderless Europe offers to criminals of all sorts, including terrorists, and the practical limitations of European intelligence in effectively countering terrorism.

9 The experience of Morten Storm, a Danish convert to Islam who became deeply involved with al-Qaeda in the Arabian Peninsula (AQAP) and who later helped Western intelligence agencies to disrupt terrorist groups, offers a unique case study on how personal vulnerabilities, particularly a lack of identity, a troubled family and a history of criminality, can sometimes lead to violent radicalisation (see Bonino 2016a; Storm et al. 2014).
} 
The most recent measures set out in the Counter-Terrorism and Security Act 2015 are aimed at keeping up with the evolving national and international terrorist threats. They represent a shift from prior legislation and policy, which were predominantly aimed at the planning stages of a terrorist attack, and instead focus on the "disruption of connections between radicalisation and planning attacks" (Fenwick 2016:12). In an attempt to deal with individuals travelling to or from the battlefields in Syria and Iraq, the Act allows security authorities to seize at ports and borders the passports of people intending to engage in terrorism-related activities abroad and permits the Secretary of State to temporarily exclude suspected terrorists from the United Kingdom via a Temporary Exclusion Order (TEO). The Act further strengthens TPIMs (Fenwick 2016). Moreover, the Act places Prevent on a statutory footing, thus devolving the delivery of some preventative counter-terrorism functions to public authorities. Universities, schools, the health sector, prisons and local authorities now have a legal duty to assess the threat of radicalisation among those with whom they work (for example: students, patients, prisoners and so on) and take appropriate action. Coupled with the problems posed by the myriad ways in which radicalisation can be defined, become manifest and be rightly or wrongly assessed, this move is emblematic of the securitisation of individuals beyond their direct involvement in or support for terrorism-related activities. ${ }^{10}$ This move links in with the proposals set out in the recently published Counter-Extremism Strategy (Home Office 2015b), which seeks to capture in its 'pre-crime net' individuals who justify violence, promote hatred and division, encourage isolation, propound alternative systems of law, reject the democratic system and carry out harmful and illegal cultural practices.

This type of approach receives support from scholars who maintain that "the difference between non-violent extremists [...] and violent extremists [...] is often only one of strategy and tactics" (Schmid 2014:18) and that, therefore, both groups should be subject to similar measures. The now-proscribed extremist al-Muhajiroun group for a long time managed to steer clear of directly instigating terrorist action but had nonetheless inspired many individuals to join violent jihad and also connected them to terrorist groups worldwide (Lowles and Mulhall 2013). Similarly, Lorenzo Vidino (2015b) notes that, in some European countries, extremist groups such as Hizb ut-Tahrir have moved from non-violent confrontation to violent militancy, thus demonstrating operational dynamics that are mutable and can allow the strategic embracement of violence at some point in the life cycle of an extremist group.

But while 'hearts and minds' approaches to curbing extremist, pro-violence views remain a sensible option (Murray et al. 2015), the targeting of both actions and ideas with the same security weapons continues to be controversial (Gearson and Rosemont 2015) and needs to be well balanced to become workable. The risk is to endanger the strategic implementation, effectiveness and credibility of preventative measures. Reducing the

\footnotetext{
${ }^{10}$ The criminalisation of members of the Kurdish diaspora in London who are not involved in preparing acts of violence and are not members of the Kurdistan Workers' Party (PKK) is a case in point. It demonstrates not only the construction of a 'moderate' versus 'extremist' Muslim narrative in the counter-terrorism world (Sentas 2015) but also shows that the criminalisation of illegal activities, such as financially and/or politically supporting the PKK, can extend to less (il)legally clear-cut situations, such as attending Kurdish community centres that authorities interpret as "instrumental extensions of the PKK because of their political work" (Sentas 2015:9).
} 
threat of terrorism requires community cooperation: overcoming distrust while generating trust (Cherney and Hartley 2015) is key in successfully enticing communities to participate in the local delivery of security. In this sense, "the logics and aims of Prevent have [often] been highly problematic in terms of [both] their positioning of Muslims as a security risk and poorly integrated into British society and the limited, and limiting, offers of engagement that have characterised participatory initiatives conducted under Prevent" (O'Toole et al. 2015:165). Perceived net-widening measures that target both violent actions and extreme views could leave some Muslim partners unwilling to collaborate and engage in participatory initiatives, as has happened with Prevent so far (O'Toole et al. 2015). Problematically, catch-all security tendencies embody a domestically emanated clash of civilisations, whereby the symbolic values of diversity shape visible, ossified boundaries between those who are considered to be the likely perpetrators of terrorism and those who are considered to be the defenders of the public good.

It is also unclear whether implementing measures that capture a whole range of extreme ideas will prevent a minority of Muslims from inspiring, supporting, planning and/or directly engaging in violent action. Wide-ranging measures could backfire and drive terrorist ideologues and their supporters further underground, eventually making security efforts all the more reliant on activities of intelligence gathering. It is crucial that the disruption of future terrorist plans does not become restricted to the difficult penetration of clandestine groups. If British policing history teaches anything, it is that infiltrating domestic extremist groups poses a myriad of operational challenges (Bonino and Kaoullas 2015) that are particularly magnified when penetrating extremist Islamist groups. The increasing threat posed by both lone actors (Alfaro-Gonzalez et al. 2015) and small cells lacking links to established terrorist networks (Europol 2015) as part of a 'decentralised jihad' (see Nesser 2015) demonstrates that terrorism manifests itself as a multifarious phenomenon that needs to be tackled through a range of diverse, flexible and targeted measures.

While critics of the British approach to the threat of terrorism have lamented the value-oriented nature of post-9/11 security measures (see, for example, Thomas 2012), they have concentrated their analysis on the level of what is (ineffective, discriminatory, unethical and so on) and what ought to be (less impactful, more participatory, better aware of Muslim grievances and so on), especially as seen from a human rights perspective. Nevertheless, further research is required to fully understand the rationale and the meanings of pervasive security responses in the aftermath of $9 / 11$ and the pragmatic feasibility of the proposed ought to be alternatives from the point of view of the state as a realpolitik actor that "pursues self-interest, [often] in violation of laws and norms [which it itself establishes through its political institutions]" (Tocci 2009:126). Arguably, the illegality ${ }^{11}$ of extensive stop-and-searches under the now-repealed Section 44 of the Terrorism Act 2000 and their alleged ineffectiveness in providing intelligence on terrorism plots and achieving prosecutions of individuals for terrorismrelated offences (Human Rights Watch 2010) make it hard to justify them on either a pragmatic or a moral basis. Notably, these measures fail to conform to those best

\footnotetext{
${ }^{11}$ As per the ruling of the European Court of Human Rights, which deemed the powers of Section 44 not to safeguard against abuses and not to be sufficiently circumscribed.
} 
counter-terrorism practices that "are achieved by patient, professional police work, carried out within the framework of normal, inherited, democratic legal processes" (English 2015:24).

The state has a range of choices at its disposal when confronting the risk that terrorism poses to national security. As Adam Roberts (2005) maintains, the American and British governments responded to $9 / 11$ by basing their War on Terror foreign policy on open confrontation. This is a position attested by the National Security Strategy for the United States (The White House 2002) and the United Kingdom's Strategic Defence Review: A New Chapter (Ministry of Defence 2002), two documents that converge in considering attack as the best defence. Instead, Roberts posits that a different set of measures would provide better results in the fight against international terrorism - that is, weakening political and governmental support for terrorist groups; tackling the various grievances that terrorists exploit to foster support; promoting democratic processes; and incentivising negotiation and tacit settlements. Other scholars, such as Lucia Zedner (2008), suggest reducing the vast array of intrusive emergency measures adopted to fight terrorism by introducing strict requirements that must be fulfilled prior to exceptional state action, such as a real, imminent and grave threat; firm evidence against one or more individuals; and the absence of less intrusive, more efficient, alternative measures.

Yet, to be effective these proposals need to transcend the realm of the idealistic and become pragmatically and politically applicable. It is not only our political culture, which favours overreaction over under-reaction (Ignatieff 2004), that is responsible for many of the heavy-handed state responses to the real and perceived risk of terrorism. As the security state has replaced the welfare state and has promoted the hollowing out of civil rights through never-ending wars against terrorism, crime, antisocial behaviour and illegal immigration (Hallsworth and Lea 2011), it is also the very nature of such a risk that de facto ties the state, which often places national security above individual liberties, to those responses. Given that the double-infinite risk of terrorism is coloured by both uncertainty and (potential) catastrophe, "the rationality of catastrophic risk translates into policies that actively seek to prevent situations from becoming catastrophic at some indefinite point in the future" (Aradau and Van Munster 2007:105; emphasis in the original). The sociopolitical disposition that appears to value the common good over individual liberties distorts the necessity of security "as one of the most basic, defining functions of the polity" (Loader and Walker 2007:97) and instead reacts to a risk which Ulrich Beck (1992) would define as being unpredictable due to its statistically unlikely and non-recurring nature. In this respect, CONTEST was born out the application of a risk management and reduction approach to countering terrorism (Gearson and Rosemont 2015). But recent research has demonstrated that, while terrorism predictions can work on a global scale, they do not manage "to assess the risk to specific cities or companies, or the absolute magnitude of attacks" (Schiermeier 2015:420), thus making preventative measures very hard to correctly engineer and direct towards specific targets. The undesired impact of these security measures on large Muslim communities therefore results not only from short-sighted strategies but also from both the existing limitations of future-oriented models of risk reduction and political orientations that seek to actively demonstrate a commitment to majority interests and public expectations of security over minority demands for equality and recognition. 
When extending our gaze beyond security to unearth the core of the project of democratic polities, Danielle Allen's reminder that "the central feature of democratic politics is [...] its commitment to preserving the allegiance of all citizens, including electoral minorities, despite majority rule" (Allen 2006:xix; emphasis in the original) is morally and ethically impeccable, yet often politically unworkable. Great Britain exemplifies the Western difficulties in keeping faith with the promise of a truly egalitarian and democratic politics in which state behaviour aims to achieve the maximisation of collective welfare. The egalitarian 'unfinished project' finds compelling evidence in the perpetuation of socio-economic inequalities across the world (European Commission 2010) and, in particular, in the record held by the United Kingdom as the only country in the Group of 7 to have experienced a rise in wealth inequality over the whole of the period 2000-2014 (Credit Suisse 2014).

A country with a long-standing tradition of being home to various religious movements and of offering asylum to fundamentalist Islamist preachers fleeing repressive, foreign societies (Hellyer 2007), Great Britain has also been lambasted for perpetuating too lax a liberalism and too stretched a Western multiculturalism (Leiken 2005), thus bequeathing ethno-cultural tensions to its future generations. Undoubtedly, a particular political philosophy can increase or reduce state governance, autonomy and power. In this respect, liberal democracy may have emerged as what Fukuyama would define as 'the ultimate Western ideology', only challenged by the lesser adversaries represented by nationalism and religious fundamentalism (Fukuyama 1989). Nevertheless, no contemporary Western political philosophies or forms of government (whether continental European dirigism or Anglo-Saxon localism) escape the strict boundaries of state political monopoly in both the distribution of security and the process of delimiting the perimeters of cultural belonging to society.

The British multicultural, pluralistic state normatively differs from, for example, the French Republican laical and secular state based on ideological sameness. While Great Britain champions equality on the basis of equal opportunities, France forges it through institutions, for example schools, where a visible identity is enforced, such as "a national identity which aims to detach individuals from their particular community of group and to assimilate them to the vast collective community which is the French nation" (Freedman 2004:10-11). Nonetheless, while the foulard affair in 1989 and the subsequent banning of Islamic symbols from public spaces pushed France to fight any visible threat to its sociopolitical and cultural stability (Freedman 2004), in the same year the Rushdie Affair highlighted a fracture between notions and practices of multiculturalism, insofar as ethno-cultural and religious differences signalled the existence of tensions between (so-called) British and (so-called) Muslim understandings of belonging to, and coexistence within, society. Whether the context is that of secondclass 'French' immigrants or 'enemies within' a British context coloured by shifting attitudes towards its Muslim population (Hudson 2007), visible diversity and outgroupness have made the symbolic clash of civilisations a lived reality for liberal societies across many Western countries. Since 9/11 the state has visibly reasserted its role as the primary distributor of security that prepares and directs counter-terrorism policies and practices that often, intentionally or unintentionally, focus on Muslims qua Muslims rather than specifically targeting individuals engaged in or supporting violent jihad. 


\section{The state 'security syndrome' and the challenges of liberal democracy}

The main element that critics of state responses to the threat of terrorism tend to gloss over is that the goal, even if not the effectiveness, of such responses might make sense when looked at from the point of view of the state as a realpolitik actor affected by a post-9/11 'security syndrome'. Arguably, the state's point of view may not necessarily, and often does not, match the aspirations of all individuals and groups that are governed within the boundaries of the polity. However, it highlights the predominance of the state in shaping ideas of security and in distributing the services of policing. State is here understood in a loosely Weberian fashion (Weber 1946 [1919]) as an entity that (a) operates through a centralised government - or a political society made up of a central bureaucracy, the police and the military (Gramsci 1971 [1947]) — which (b) governs a clearly delimited geographical territory, (c) upon which it exerts political and legal powers, (d) in particular by holding monopoly of the legitimate use of physical force, (e) through which it exerts domination. It would certainly be simplistic to consider the modern state as a monolithic entity. Instead, it includes a complex vortex of agencies and institutions with connections to business, charities and civil society. Furthermore, while the state is the predominant, yet not the monopolistic, provider of security, there exist a multitude of actors and agencies, such as private security and civil society, which are also involved in the process of securitisation (Loader and Walker 2007).

The modus operandi of the British counter-terrorism apparatus itself relies upon a multiagency delivery of security between central government, local government, police forces, charities and other publicly funded bodies. This model is behind the Prevent strategy and initiatives originating within Prevent, such as 'Channel', an earlyintervention programme that aims to "identify and provide support to individuals who are at risk of being drawn into terrorism" (Home Office 2015c:3). This multiagency approach has not been unproblematic. Recent research (O'Toole et al. 2015) has highlighted both ongoing tensions among the Home Office (Office for Security and Counter-Terrorism), the Department for Communities and Local Government and the Foreign and Commonwealth Office, driven by their different logics and practices of working with Muslim communities under Prevent, and the reluctance of local authorities $^{12} 13$ to engage in such a strategy (see also Alam and Husband 2013). But, despite the existence of a networked plurality of security providers in the realm of counterterrorism and the fact that within Europe alone there are fundamental differences

\footnotetext{
12 This became very apparent during a community cohesion event organised in a city within the Yorkshire and Humber region in July 2015. Both the organiser of the event and a City Council representative informed Stefano Bonino of the importance of leaving any 'Prevent' and/or 'extremism'-related language out of the speech that he was scheduled to deliver to leaders of the Muslim community, teachers, members of the armed forces and other parties.

${ }^{13}$ Several academics have also openly resisted the implementation of Prevent in universities (The Independent 2015; The Guardian 2016). However, a minority of academic voices (Farrar 2015; Times Higher Education 2016) have expressed concerns at the fact that some scholars associate with, or give an unchallenged platform to, reactionary Islamists who openly sympathise with violent jihad. Official claims about al-Qaeda's secret recruitment in British universities and colleges dates at least as far back as 2005 and are contained in a joint Home Office and Foreign Office report entitled 'Young Muslims and Extremism' (Hoffman 2014).
} 
between the aspirations and operations of states vis-à-vis security, ${ }^{14}$ the post-9/11 climate has witnessed the emergence of a 'security syndrome' in the form of

A certain clawing back by the state of pluralized security authority in favour of a reassertion of the importance of 'old' state agencies (the police, intelligence services, military) as well as the formation of 'new' ones such as the Department of Homeland Security in the USA and the Serious and Organized Crime Agency [later replaced by the National Crime Agency] in the UK. (Loader and Walker 2007:199)

Moreover, the fragmentations and complexities of state-related or associated agencies in governing and securing society still do not turn the state into such a heterogeneous, fuzzy entity that its conceptual totality becomes indiscernible. While the securitisation of Muslims is also carried out by non-state actors ranging from private security officers to public sector professionals with a duty of care (Blackwood et al. 2012), even more so following the Counter-Terrorism and Security Act 2015, the legitimacy of such actors' actions is provided by top-down state-directed legislation, policies and political deliberations. In other words, non-state security actors and local agencies do not exist in a vacuum but are informed, if not encouraged, by state and political orientations towards order and security, especially in the post-9/11 empowerment of governments and security institutions that have devised national strategies such as CONTEST, have funded some organisations (for example, the Radical Middle Way) rather than others (for example, the Muslim Council of Britain) and have steered local engagement with vulnerable communities in the directions set out in Prevent. Lastly, the process of moving away from, and devolving some of, its 'rowing' functions (delivering the services of policing and security) in favour of stronger 'steering' functions (legitimising, regulating and distributing the services of policing and security) (Osborne and Gaebler 1992) has made the state "more active-demanding a greater degree of the very authority and legitimacy that the move towards multi-actor governance threatens to undermine" (Loader and Walker 2007:121).

The counter-terrorism measures which have been rolled out in Great Britain take place in a Western political context in which scholars have for the past few decades noticed the emergence of a penal state (Wacquant 2009) that shapes a disciplinary society (Foucault 1977) grounded on a pervasive culture of control (Garland 2001); elevates crime to everyday fear; promotes ontological insecurity (Giddens 1991); and erodes social trust (Simon 2007). Conceptually, by being the focus of policing measures and by sharing the same faith with a tiny number of violent Islamists, some Muslims have become the trademark of negatively perceived diversity, whose rights risk being trumped in the name of an all-pervading security mantra and whose

\footnotetext{
${ }^{14}$ At the institutional level, one may note the centralised and militaristic system of policing (French Gendarmerie Nationale, Italian Arma dei Carabinieri, Spanish Guardia Civil and so on) typical of continental European countries versus the British orientation towards localism (territorial police forces). So far as specific European approaches to countering radicalisation are concerned, Vidino and Brandon (2012) highlight the cultural, political and legal peculiarities that inform the different strategies that have been rolled out in the United Kingdom, the Netherlands, Denmark and Norway.
} 
marginalisation can allay the anxieties of the broader population and, in turn, sustain the 'state of security'.

Some counter-terrorism measures have failed to surgically target terrorists and their supporters and, instead, have focused their attention on individuals far and wide. This is nowhere more evident than in Great Britain where "between 2001 and 2010 there were 1,834 terrorism-related arrests [...], from which 404 people were charged, 332 prosecuted and 237 convicted of terrorism-related offences" (Choudhury 2012:30). The fact that $13 \%$ of those arrested for terrorism-related offences were eventually convicted for such offences demonstrates that the national security impetus is not entirely misplaced. At the same time, it demonstrates that the same impetus has problematically endangered the civil liberties of $87 \%$ of people arrested, who were later found not to be guilty of terrorism-related offences. Evidence from quantitative studies shows that, particularly in the first few years after September 2001, offenders motivated by Islamist ideologies received significantly longer sentences than those motivated by other ideologies (Amirault and Bouchard 2015). Ultimately, the increased security focus on a whole religious community and the erosion of civil liberties becomes not only a political and moral issue but also poses a wider social and cultural risk. Research demonstrates that public acceptance of civil liberties' reduction is strictly confined to a clear transnational terrorist threat and to a perception that related policies will prevent future acts of terrorism. Conversely, domestic terrorism threats and policies designed to counter such a threat are much less likely to gain public support (Garcia and Geva 2016). The intermingling of political discourses and counter-terrorism law, policy and practice creates a powerful mix that can both encourage hostility and hatred towards Muslims (Mythen et al. 2009; Poynting and Mason 2006; Pantazis and Pemberton 2009) and endanger the cooperation of communities in the local delivery of security measures. This speaks not just of the British state as a security actor but also of the capacity of Western democracy to cater for, and effectively deal with, its increasingly ethno-culturally and religiously diverse population. ${ }^{15}$

Democracy - the cradle of Western fairness and egalitarianism, and often opposed to the theocratic authoritarianism of part of the Muslim world - is often premised upon, and ritualised through, the necessity of sacrifice and the inevitability of extreme loss. This is skilfully spelled out in Allen's (2006) masterpiece Talking to Strangers: Anxieties of Citizenship Since Brown v. Board of Education:

Democracies are supposed to rest on consent and open access to happiness for their citizens. In the dreamscape of democracy, for example à la Rousseau, every citizen consents to every policy with glad enthusiasm. No one ever leaves the public arena at odds with the communal choice, no one must accept political loss or suffer the imposition of laws [to] which she has not consented. But that is a dream. [...] Since democracy claims to secure the good of all citizens, those

\footnotetext{
$\overline{15}$ Ethnic diversity is not a national 'necessity'. Rather, it is a political, institutional and social choice as well as the outcome of cultural and economic processes of globalisation. There still exist economic powers and strong liberal democracies that are ethno-racially homogeneous, for example Japan (about $98.5 \%$ ethnic Japanese) and South Korea (also known as Dan-il minjok guk ga, or 'the single race society', which has over $99 \%$ ethnic South Koreans).
} 
people who benefit less than others from particular political decisions, but nonetheless accede to those decisions, preserve the stability of political institutions. Their sacrifice makes collective democratic action possible. [...] The hard truth of democracy is that some citizens are always giving things up for others (Allen 2006:28-29).

The founding principles underpinning Western democracies vary and have spurred much debate. The very fact that democracy binds together federations, confederations and international regimes is part of a universalising state phase that has replaced the politics of empires (Huntington 1996), thus shifting our understanding of political life. While the United States is grounded on equality, liberty, individualism, populism, laissez-faire and, more generally, an Anglo-Protestant culture of ethnic traditions, European states tend to foster national identities based on blood and soil (Fukuyama 1989). Although Francis Fukuyama rightly notices that a problem inherent in group rights in liberal democracies is that not every group necessarily upholds liberal values and that equality should be granted to individuals qua individuals and not as members of cultural communities, he fails to account for the higher communal order represented by the state.

Such an order has faced difficulties in reconciling national security with civil liberties, as demonstrated by the securitisation of Muslims (as a sociocultural group) in the process of reducing the risk posed by Islamist terrorism. In this sense, the call to "remain vigilant, not just about the terrorist risk, but also about forms of control which unjustly vilify and criminalize law-abiding communities" (Mythen and Walklate 2006:395) reminds scholars of the perils of uncritically accepting the goodness of liberal democratic state action. Moreover, the securitisation of Muslim communities can undermine equal participation in what are already unequal social and political spheres. Arguably, inequalities are not a novelty of the twenty-first century. As history teaches, at no point since the mid-seventeenth-century's spread of the Westphalian system of sovereignty and the nineteenth-century's flourishing of nation states, and much less so in the previous geopolitical arrangements of empires and smaller states, has a society fulfilled its egalitarian dream. To remain closer to the recent past, in the twentieth century no major nation state is known to have existed that did not encompass profound social differences and inequalities. Italy in the early 1900s, the United Kingdom (technically a multinational state) throughout the two World Wars, France in the postwar period, Japan in the 1960s, Germany in the 1990s and any other European country during the Long Peace (from 1945 until today) have all been fragmented and had exclusionary polities. Despite living in one of the most peaceful eras in the history of humankind and despite an ongoing global process characterised by political democratisation, the spread of civil rights, the reduction of inequalities and increased access to education (Pinker 2011), modern states are still far from treating all of their citizens equally.

On the one hand, this follows a historical continuum that has arrived at the sanctification of the state at the expense of local social aggregates. Robert Putnam famously explored the ongoing atomisation of society and the decline in social capital (bonding social capital plus bridging social capital). As social networks between homogeneous groups (bonding social capital) have weakened, Putnam (2000) maintains, similar networks between heterogeneous groups (bridging social capital) have 
withered away too, resulting in tensions among ethnic communities. At the local level 'skirmishes' amongst civilisations can only find fertile ground. Paradoxically, instead of curing the illnesses of intermediate forms of association (family, neighbourhood, trade unions, churches, et cetera), people have fulfilled their social need for community by building totalising entities, namely states, which concentrate power within central governments (Nisbet 1953). The 'security syndrome' affecting the British state approaches the reduction of risks at the macro level of national law and order, thus highlighting "the fact that the policy response to risk, danger, threat and uncertainty is primarily based on the resurgence of sovereign and authoritarian forms of rule" (Campbell 2011:161-162). The suspension of legal determinations, such as the distinction between the public and the private spheres, brought about by the juridical void of a "'state of exception' [...which] appears as a threshold of indeterminacy between democracy and absolutism", (Agamben 2005:3) compels further caution concerning the absolute empowerment of the state in conceptualising and directing security. Moreover, the fact that extra security measures create a culture of suspicion that endangers trust and social cohesion (Herbert 2012) poses important questions about the trade-off between security, on the one side, and community relations and individual liberties, on the other side.

On the other hand, the socio-demographic situation of minorities and the political fragmentation $^{16}$ of Muslims in Great Britain place diversity in an unequal relationship with community cohesion. Great Britain lacks the cultural mix of Northern Ireland, which is composed of "longstanding and now approximately equally-sized communities" (Herbert 2012:357). In lacking such a distinctiveness and being, instead, "a product of rapid immigration creating a multicultural, multi-religious society within a couple of generations" (Herbert 2012:357), Great Britain is still coming to terms with its ethno-cultural fragmentations. Such fragmentations have been publicly reasserted both by illiberal actions epitomised in the burning of Salman Rushdie's Satanic Verses in Bradford in 1989 and in the post-9/11 social process of constructing a Muslim Other. The idea of nation as a moral conscience based on collective solidarity and imagined common history (Renan 1939) and as an intersubjective reality existing in collective imaginations yet playing a key role in binding people together (Harari 2014) is all the more powerful when deployed through the political symbols of an attack on British values. The British government wisely considers fundamental values to be democracy, the rule of law, individual liberty and tolerance of different beliefs and faiths (Home Office 2015b). Consequently, extremism is the vocal or active opposition of such values. Extremism, the British government suggests, "divides communities and weakens the social fabric of our country" (Home Office 2015a:37) and warrants cultural self-defence (Cameron 2011). But readers should not forget that extremism

\footnotetext{
${ }^{16}$ The Muslim Council of Britain (MCB) was set up in 1997 to act as an umbrella institution including around 400 organisations, mosques and schools, to give voice to Muslim communities. Yet, the MCB was mainly grounded in ideologies springing from the Middle Eastern and South Asian anti-colonial political Islam and was particularly resented by traditional, conservative and apolitical Muslim groups that did not affiliate to it. Furthermore, as Archer (2009) shows, in a poll conducted in 2007 only $6 \%$ of Muslims felt represented by the MCB. Following 2001, the British government started to find new ways to govern its Muslims and distanced itself from the MCB, in a context in which, Modood and Salt (2011) argue, integration, citizenship and group identity formation became a prime political concern, especially after $7 / 7$.
} 
partly emerged as a by-product of British state policies of tolerance towards fundamentalist preachers who arrived in the country in the 1980s and 1990s, who established a foothold in London (Nesser 2015) and who encouraged "followers to adopt extreme political narratives and pursue activities designed to support the global fundamentalist struggle" (Herrington 2015a:15). An informal agreement (Clarke 2005) was established between security authorities and fundamentalist preachers such as Omar Bakri Muhammad, Abu Hamza al-Masri and Abu Qatada al-Filistini: extreme views, including open support for violent jihad, were tolerated so long as British streets were to be left free of blood. This controversial, informal agreement was put to the test on 7 July 2005, when four Islamist terrorists attacked the London transportation system, killing 52 people and injuring more than 700. On that day, long-standing concerns French, ${ }^{17}$ American and other non-British authorities had had that Great Britain had been naively breeding its own terrorists proved to have been not entirely misplaced.

However, 'extremism' is not a watertight category. The scales of extremism are manifold and political responses must be tailored around indicators of a security threat to society. This exercise is certainly fraught with political and social complexities and ambiguities. Lorenzo Vidino's (2010) detailed analysis of the genesis and evolution of the Muslim Brotherhood in the West demonstrates that clearly assessing the stances of people bound by a political ideology (Islamism), rather than membership, a constitution and a common strategic direction, is very difficult. While optimists find the 'Brothers' to be democratic Islamists who can be a useful tool in countering violent jihadi propagan$\mathrm{da}$, pessimists believe that they both hide a more sinister goal to gradually impose Islam on Western societies and maintain ambivalent stances toward violence, as expounded during private meetings and in the writings of its intellectual leader Yusuf al-Qaradawi (Vidino 2010). Donald Holbrook (2014) masterfully elucidates these tensions when he compares democratic Islamists, such as members of the Muslim Brotherhood, to social democrats and Islamist militants, such as members of al-Qaeda, to communist revolutionaries. Holbrook (2014:27) posits that "there are some vague similarities in terms of worldviews and perceptions but stark differences in terms of methods and direction". Social and political suspicions toward democratic Islamists can therefore be considered a risk-averse stance toward groups whose long-term trajectory is hard to predict.

This paper contends that limiting the freedoms of individuals who openly and consistently sympathise with a violent jihadi group, even when falling short of involvement in and/or direct support of terrorism, is justifiable in the interests of the public

\footnotetext{
${ }^{17}$ In a rarely available insight (Hassaïne and Barling 2014) into the machinations of the intelligence apparatus, Réda Hassaïne, an informer for the British, French and Algerian security services who infiltrated Finsbury Park Mosque in London, recounted that, in the late 1990s, the French government grew extremely concerned about the hands-off approach taken by British authorities toward fundamentalist preachers in London. Amid worries that the Armed Islamic Group (GIA) could strike in France during the football World Cup 1998, the head of the Direction Générale de la Sécurité Extérieure (DGSE) in London, codenamed 'Jerome', devised two outlandish plans to deal with Abu Hamza al-Masri, the Egyptian imam of Finsbury Park Mosque and a supporter of both the GIA and al-Qaeda. 'Jerome' planned to have Abu Hamza al-Masri assassinated and to later blame his death on British far-right groups. Alternatively, he proposed to kidnap and bundle Abu Hamza al-Masri into a van and take him to France via the Eurotunnel so that he could be prosecuted there. Neither of the two plans became operational and Abu Hamza al-Masri continued to preach until he was arrested in 2004. He was later extradited to the United States in 2012, convicted of terrorism charges in 2014 and sentenced to life imprisonment in 2015 (Chon 2015).
} 
good. Nonetheless, in free societies based upon the rule of law and the protection of freedoms of expression, placing legal restrictions on other extreme stances that run counter to both the views of the majority and the established democratic order but that fall short of involvement in and/or direct support for terrorist and/or subversive activities is very difficult. For instance, the utopian idea of living in a Caliphate rather than the actual practice of attempting, or encouraging others, to establish one remains in the realm of abstract, rather than actionable, belief. The fact that around $60 \%$ of terrorists are involved in other criminal activities ${ }^{18}$ (Intelligence and Security Committee 2009) demonstrates that past actions, rather than ideas alone, can sometimes be better indicators of future potential involvement in terrorism. Extremists holding non-actionable beliefs could well be mobilised for targeted, short-term and last resort activities of police-Muslim partnership within hard-to-reach communities, where street credibility counts more than professional qualifications. Police engagement with nonviolent fundamentalists, in particular Salafis, managed to steer violent fundamentalists away from terrorist action in London (Lambert 2008, 2011). By carefully drawing the boundaries of extremism around politically pragmatic and socially more acceptable contours, governments can avoid the risk that net-widening counter-terrorism measures will fuel the rhetoric of an inevitable domestic cultural clash of civilisations. Such a clash is often energised by confusing Muslim diversity, for example the more socially conservative attitudes displayed by British Muslims compared to non-Muslim Britons (Lewis and Kashyap 2013), and Muslims' perceived threat both to ethnically and racially fixed notions of English nationhood ${ }^{19}$ (Fenton and Mann 2011) with a threat to public security.

Recent estimates that about $15 \%$ of British Muslims consider suicide bombings to be sometimes justified (Tausch 2015) ${ }^{20}$ warrant a critical reading. Meer (2014a) reminds us of the need to exert much caution when interpreting polls that, in the past decade, have suggested tacit support for terrorism among a variably larger or smaller section of the British Muslim community. The threat posed by violent Islamists and their supporters has also played into the hands of wider sociocultural insecurities and worries about an 'Islamisation of Europe' (Caldwell 2009; Fallaci 2004). Within this context, the post-9/11 security climate demonstrates Turner's liberal paradox - that is, the state meddling in "the management of religions in the interests of civil harmony" (Turner 2012:1060), despite its commitment to regard religion as an issue of private conscience-and highlights a further hurdle in dealing with interwoven issues of religion, culture and security.

The adoption of net-widening approaches that impact on Muslim communities at large have achieved political consensus in the drafting of legislation and the deployment of measures that have not differed considerably with different governing parties (Labour between 1997 and 2007, Conservative/Coalition between 2010 and 2015 and Conservative since 2015), other than the institutional move of responsibility for

\footnotetext{
${ }^{18}$ Petter Nesser's (2015:10) detailed study of Islamist terrorism in Europe also found that "it was not uncommon for jihadis in Europe to have criminal records".

${ }^{19}$ For an assessment of the peculiar Scottish engagement with Muslim diversity, see the work of Stefano Bonino (2015a, b, 2016c).

${ }^{20}$ The same study estimates that, on average, about $17 \%$ of Muslims worldwide openly express sympathies for groups such as al-Qaeda, the Taliban, Hezbollah and Hamas (Tausch 2015).
} 
addressing extremism from the Department for Communities and Local Government (under the Labour government), which worked through a wider social cohesion agenda, to the Home Office (under the Conservative/Coalition government), which took a more security-oriented approach. The ethos of British counter-terrorism measures itself has also remained largely unchanged, save for minor practical alterations (for example, control orders being transformed into TPIMs), additional powers introduced by the Counter-Terrorism and Security Act 2015 and legislative changes (for example, the scrapping of Section 44 of the Terrorism Act 2000) driven more by European legal pressures than out of an institutional willingness to rectify mistakes.

Similarly, in the United States, the Uniting and Strengthening America by Providing Appropriate Tools Required to Intercept and Obstruct Terrorism Act of 2001 (also known as the Patriot Act) was signed into law by Republican president George Bush in October 2001 and then partially extended by Democratic president Barack Obama 10 years later, in a political context that has progressed, yet has not brought major changes to national attitudes and foreign policies focusing on the threat of terrorism. Despite variations in the present and past delivery of counter-terrorism, the involvement of non-state actors and the blurring of security and community cohesion policies (O'Toole et al. 2015), there remains a political continuum across Western liberal democracies in the distribution of security through a state-directed approach that elevates the fight against terrorism to a top national priority but fails to properly address three key interconnected issues: respecting civil liberties, maintaining community relations and fostering social cohesion. Notably, it is a contention of this paper that counter-terrorism measures have signalled an increasing political and cultural distance between the British state and Muslim communities, which symbolically transposes Huntington's clash of civilisations to within the national boundaries of the polity.

\section{Beyond Huntington: from global clashes to national tensions}

Tensions between Great Britain and Muslim communities are once again close to breaking point, 27 years after the Rushdie Affair, 15 years after the English riots in 2001 and September 11 and 11 years after the London bombings, while the often stereotyped, yet very complex, relationship between the West and the world of Islam(s) is once again balancing on a thin wire. While the Islamic State continues to bring destruction in the Middle East and heightens fears in Europe and North America, counter-terrorism measures recently proposed in Europe (Bigo et al. 2015a, b) and rolled out in Great Britain to deal with the evolving global threat posed by Islamist terrorism reenergise the evergreen debate around the Huntingtonian clash of civilisations.

Controversial, widely disputed and yet highly popular, Huntington's concept of the clash of civilisations (Huntington 1993) is the most prominent recent theory that has seriously questioned the possibility of integration and dialogue between Islam and the Western world. Influenced by the civilisational approaches to history proposed by Spengler (1927) and Toynbee (1974 [1934/1939]), as well as by Lewis's (1990) first coinage and exploration of a supposed post-Cold-War clash of civilisations and cultural struggle between the West and Islam, Huntington's theory foresaw conflicts and tensions between the Western world and the Muslim world. According to Huntington, these two worlds would clash militarily due to inherent cultural and religious 
differences and the realities of the modern political and economic systems. The relevance of Huntington's theory to current discourses on the relationship between Islam and the West, including the post-9/11 Western securitisation of Muslims, is unquestioned. It is one of the most commented-on political theories of the last 25 years and has fuelled endless debates.

Its detractors have considered it a modern form of Orientalism - that is, an approach that implies a Western positional superiority operating as "a style of thought based upon an ontological and epistemological distinction made between 'the Orient' and (most of the time) "the Occident'" (Said 2003 [1978]:2). Detractors have also attempted to demolish it on various grounds. Empirically, Russett et al. (2000) demonstrate that conflicts tend to happen primarily within the Muslim world rather than between Western and Muslim countries (see also Fox 2001; Henderson and Tucker 2001). The current conflict in Syria and Iraq is a case in point. Philosophically, Ali Mazrui (2001) argues that the two worlds feed each other in a relationship of mutual cultural and demographic interdependence. Normatively, Fouad Ajami (1993) suggests that states act upon self-interest and are not a direct emanation of civilisation-based identities. On the other side of the spectrum, a few scholars have provided arguments directly or indirectly in support of Huntington's theory. Hans Magnus Enzensberger (2006) forcefully condemns Arab countries for lacking political freedoms, failing to meet democratic standards, boasting high levels of corruption, being economically underdeveloped, overlooking education and knowledge and discriminating against women. Norris and Inglehart (2003) posit that the Western world and the Muslim world clash over eros - that is, the lack of recognition of self-expression values in Muslim-majority countries, namely gender equality and sexual liberation.

Nasar Meer (2014b) presents a more nuanced picture of Islamic-Western relations when he maintains that historical colonial dynamics still inform contemporary postcolonial environments and notes that European civilisation has historically struggled to incorporate difference into its conceptualisation of common life. Global surveys provide further evidence of the complex and heterogeneous relationship between Westerners and Muslims (Pew Global Attitudes Project 2006, 2011), which escapes any black-and-white characterisation. Attitudes towards Muslims vary greatly across European countries, where populations in Spain (52\%), Germany (69\%), the United Kingdom (72\%) and France (76 \%) hold much more favourable views of Muslims compared to people in Poland (30\%) and Italy (31\%) (Pew Global Attitudes Project 2015).

This speaks of an imperfect European project of 'cultural conversation', whereby what Coles (2009) identifies as converging Islamic and Western values are yet to be fully recognised by diverse national constituencies. Moreover, this imperfect European project highlights ongoing difficulties in implementing a neutral state, or a moderate secular state (Modood 2010), which has emerged since the mid-1970s within circles of European political philosophers, is broadly connected with the thoughts of John Stuart Mill, Immanuel Kant and John Locke and is supposedly open to the accommodation of different religions (Madeley 2003). Ongoing cultural frictions in Great Britain over sharia law courts (Zee 2016) and forced marriage (Bonino 2016b) also suggest that the more conservative sections of the Muslim community still struggle to adapt to existing legal frameworks and social norms, thus placing Muslim diversity in a weak position when it seeks to negotiate group-based demands in the contested arenas of security. 
Serious global tensions between the Western world and the Muslim world are probably better defined in terms of hostilities between either a specific set of nation states or Western nation states and violent Islamist/jihadist groups. The United States, often with support from its British ally, has been particularly active in responding to much of the provocation received from Middle Eastern, Asian and Arab Muslim states and/or groups by waging wars (for example, Afghanistan and Iraq) and taking military measures (for example, Pakistan) to curb terrorism-related hostilities between the Western world and the Muslim world, and by offering political and/or military support to various conflicts within the Muslim world (for example, Israel-Palestine, Libya, Syria and Iraq). Richard English (2009) wisely argues that military responses can backfire and generate the very terrorism that they seek to combat: the increase in terrorism and violence both within and beyond ${ }^{21}$ Iraq is a notable example (English 2015). Donald Dannreuther (2007) further posits that the war in Iraq directly fed political rhetoric and served the interests of jihadists who have capitalised on Western foreign policy's faux pas by fostering support for their violent causes in European and Middle Eastern countries. On their side, Islamist terrorists have often exploited the rhetoric of Western imperialism, rather than using religion qua religion, to justify and execute spectacular acts of 'resistance' (Levi 2007)_elsewhere more properly defined as 'terrorism",22 (Schmid 2011).

Since 9/11, these global clashes have occurred in a cultural and more local formthat is, through the domestic reminders that the West has offered its Muslim citizens that Muslim diversity is problematic. These reminders have often entailed the securitisation of Muslims (Kundnani 2014) and have followed a sociopolitical continuum in the shaping of public perceptions of those who, over 15 years ago, were considered 'dangerous strangers' (Zolberg and Woon 1999) and who are now popularly deemed to be members of a 'suspect community' (Pantazis and Pemberton 2009). Moreover, these reminders have normalised wide-ranging exceptional measures to deal with Islamist terrorism, in a context in which various studies (Kurzman 2012; LaFree et al. 2010; Mueller 2006) demonstrate that the terrorist threat, while serious, needs to be viewed in proportion. In the twenty-first century, Western Europe has been much safer than in the last 30 years of the twentieth century: the Global Terrorism Database (York 2015) shows that, between 2000 and 2015, terrorist activities resulted in more than 100 casualties per annum only in 2004 (Madrid attack) and in 2015 (Paris attack). This figure is in stark comparison with the previous 30 years (1970-1999), 23 of which saw more than 100 casualties every year as a result of violence perpetrated by the Irish Republican Army in the United Kingdom, the Euskadi Ta Askatasuna in Spain and other terrorist groups across Europe. Richard English (2015:24) correctly reminds us "how comparatively limited terrorism-generated levels of death and injury actually are

\footnotetext{
${ }^{21}$ Petter Nesser's (2015) study demonstrates that European involvement in conflicts in the Muslim world, as well as events considered to be offensive to Islam and the Prophet Muhammad (notably, the Danish cartoons in 2005) and sustained campaigns by the GIA and al-Qaeda, have historically inspired many terrorist plots against European countries and interests.

${ }^{22}$ Here this term accords with (an extract of) the 'revised academic consensus definition of terrorism as "calculated, demonstrative, direct violent action without legal or moral restraints, targeting mainly civilians and non-combatants, performed for its propagandistic and psychological effects on various audiences and conflict parties" (Schmid 2011:86).
} 
when set against more major threats". In this respect, domestic overreactions to the threat of terrorism risk delegitimising the state and its political, legal and security apparatus within Muslim communities, effectively undermining the same institutions that counter-terrorism efforts should safeguard.

This paper contends that, in Great Britain, global hostilities have sparked cultural domestic tensions in a context in which Muslims have become "a national security concern, the focus of state intervention and political management, and subject to wideranging suspicions around loyalties to the country of residence/citizenship" (Lynch 2013:257). The British government has responded to the real and perceived threat of Islamist terrorism by consciously or unconsciously feeding into the symbolism of a clash of civilisations between its non-Muslim majority and its Muslim minority through practices broadly aimed at securitising not only violent Islamists and their supporters but also wider Muslim communities. Net-widening notions and practices of counterterrorism, which seek both to reduce risk and uncertainty and to reassert state monopoly over the distribution (if not always the delivery) of security, have inadvertently signalled a further cultural distancing between British society and Muslim communities, with potentially negative consequences for the shaping of a pluralistic yet cohesive society.

\section{Concluding remarks}

The iconography of destruction and death supplied by the terrorist attacks of $9 / 11$ is a powerful image still pervading Western minds: it reinforced the image of the Orient as a mystical power and undermined the notion that the United States is an unbeatable superpower (Ibrahim 2007). At the time of writing, the US-led international coalition is carrying out relentless air strikes in Syria in order to vanquish the Islamic State, showing the "continuing role of force as a factor in the calculations and actions of governments" (Roberts 2012:180). As both the Islamic State and al-Qaeda reassert the importance of targeting the Western 'far enemy', a key principle of al-Qaeda's original doctrine (Europol 2015), international military intervention in the absence of a long-term strategy to stabilise a turbulent Middle East (Habeck et al. 2015) and to solve the "societal and political failures in Iraq and Syria" (Lister 2015:11) risks provoking terrorist retaliation against Western powers involved in the conflict. Meanwhile, the British net-widening security approach has fallen into the political trap set up by Islamist terrorists and has fuelled the rhetoric of a domestic clash of civilisations. Politically naïve preventative approaches will continue both to problematise much-needed mutual engagement with Muslim communities and local authorities and to inform similarly contested European strategies (Bigo et al. 2015a). Ongoing public concerns that counter-terrorism legislation and strategies are the consequences of an excessive state focus on Muslim diversity must be counteracted with more positive narratives and actions. Otherwise, these concerns will both affect community confidence in the security apparatus and undermine the effectiveness of those measures that directly target violent Islamists and their supporters. Far from 'civilising security' (Loader and Walker 2007) and showing strategic astuteness in its fight against terrorism, the British state is accidentally playing into the hands of violent 
Islamist recruiters who prey on young Muslims who are culturally alienated, socially discriminated against and politically disenfranchised.

While this paper has demonstrated some positive aspects of Western-Islamic relations, ongoing tensions over the practices of inter-ethnic and inter-religious coexistence-for example, as indicated by significant levels of public concern over Muslim integration in British society (YouGov 2013), a higher threshold for being considered British and generally negative views of immigration held by one in two Britons (Kiss and Park 2014)_raise questions regarding the relationship between British society and cultural diversity. The discrimination of Muslims in Great Britain, the United States and elsewhere (for example, Australia; see Noble 2005) provide evidence of persistent, albeit varying, negative Western attitudes towards Islam in a context in which bottomup opportunities for positive inter-ethnic contact are seriously needed in order to foster good inter-community relations (Bekhuis et al. 2013). The twentieth and the twentyfirst centuries may be the most peaceful eras in the history of humankind (Pinker 2011), yet the march towards social justice and equality in Great Britain, and in the West more generally, needs to overcome the state 'security syndrome' and find ways to cure the malaise of terrorism and violent extremism without giving up on inter-community relations, social cohesion and civil liberties.

Open Access This article is distributed under the terms of the Creative Commons Attribution 4.0 International License (http://creativecommons.org/licenses/by/4.0/), which permits unrestricted use, distribution, and reproduction in any medium, provided you give appropriate credit to the original author(s) and the source, provide a link to the Creative Commons license, and indicate if changes were made.

\section{References}

Agamben, G. (2005). State of exception. Translated by K. Attell. Chicago: University of Chicago Press.

Ajami, F. (1993). The summoning. Foreign Affairs, 72(4), 2-9.

Alam, Y., \& Husband, C. (2013). Islamophobia, community cohesion and counter-terrorism policies in Britain. Patterns of Prejudice, 43(3), 235-252.

Alfaro-Gonzalez, L., Barthelmes, R. J., Bartol, C., Boyden, M., Calderwood, T., Doyle, D., Green, J., Herro, E., Johnson, T., Lawrenz, K., McMaster, K., Nencheck, M., Noronha, N., Lee, S., Walsh, K., Wu, L., \& Yee, K. (2015). Report: Lone wolf terrorism. Washington: Georgetown University.

Allen, D. (2006). Talking to strangers: Anxieties of citizenship since Brown v. Board of Education. Chicago: University of Chicago Press.

Amirault, J., \& Bouchard, M. (2015). Timing is everything: the role of contextual and terrorism specific factors in the sentencing outcomes of terrorist offenders. European Journal of Criminology. doi:10.1177/ 1477370815578194.

Aradau, C., \& Van Munster, R. (2007). Governing terrorism through risk: taking precautions, (un)knowing the future. European Journal of International Relations, 13(1), 89-115.

Archer, T. (2009). Welcome to the umma: the British state and its Muslim citizens since 9/11. Cooperation and Conflict: Journal of the Nordic International Studies Association, 44(3), 329-347.

Bartlett, J., \& Birdwell, J. (2010). From suspects to citizens: Preventing violent extremism in a big society. London: Demos.

Beck, U. (1992). Risk society: Towards a new modernity. London: Sage Publications.

Bekhuis, H., Ruiter, S., \& Coenders, M. (2013). Xenophobia among youngsters: the effect of inter-ethnic contact. European Sociological Review, 29(2), 229-242.

Bigo, D., Brouwer, E., Carrera, S., Guild, E., Guittet, E.-P., Jeandesboz, J., Ragazzi, F., \& Scherrer, A. (2015a). The EU counter-terrorism policy responses to the attacks in Paris: towards an EU security and liberty agenda. CEPS Paper in Liberty and Security in Europe 81 (February). 
Bigo, D., Carrera, S., Guild, E., Guittet, E.-P., Jeandesboz, J., Mitsilegas, V., Ragazzi, F., \& Scherrer, A. (2015b). The EU and its counter-terrorism policies after the Paris attacks. CEPS Paper in Liberty and Security in Europe 84 (November).

Blackwood, L., Hopkins, N., \& Reicher, S. (2012). Divided by a common language? Conceptualizing identity, discrimination, and alienation. In K. Jonas \& T. Morton (Eds.), Restoring civil societies: The psychology of intervention and engagement following crisis (pp. 222-236). Oxford: Wiley.

Bonino, S. (2012). Policing strategies against Islamic terrorism in the UK after 9/11: the socio-political realities for British Muslims. Journal of Muslim Minority Affairs, 32(1), 5-31.

Bonino, S. (2013). Prevent-ing Muslimness in Britain: the normalisation of exceptional measures to combat terrorism. Journal of Muslim Minority Affairs, 33(3), 385-400.

Bonino, S. (2015a). Scottish Muslims through a decade of change: wounded by the stigma, healed by Islam, rescued by Scotland. Scottish Affairs, 24(1), 78-105.

Bonino, S. (2015b). Visible Muslimness: between discrimination and integration. Patterns of Prejudice, 49(4), $367-391$.

Bonino, S. (2016a). In conversation with Morten Storm: a double agent's journey into the global Jihad. Perspectives on Terrorism, 10(1), 53-64.

Bonino, S. (2016b). Policing forced marriages among Pakistanis in the United Kingdom. In M. Malloch \& P. Rigby (Eds.), Human trafficking: The complexities of exploitation (pp. 159-174). Edinburgh: Edinburgh University Press.

Bonino, S. (2016c). Muslims in Scotland: The making of community in a post-9/11 world. Edinburgh: Edinburgh University Press.

Bonino, S., \& Kaoullas, L. (2015). Preventing political violence in Britain: an evaluation of over forty years of undercover policing of political groups involved in protest. Studies in Conflict and Terrorism, 38(10), 814-840.

Brodeur, J.-P. (1983). High policing and low policing: remarks about the policing of political activities. Social Problems, 30(5), 507-520.

Caldwell, C. (2009). Reflections on the revolution in Europe: Immigration, Islam and the West. London: Allen Lane.

Cameron, D. (2011). PM's speech at Munich security conference. Speech delivered at Munich Security Conference, Munich, 5 February 2011. http:/www.gov.uk/government/speeches/pms-speech-at-munichsecurity-conference. Accessed 6 December 2015.

Campbell, E. (2011). The cultural politics of justice: Bakhtin, stand-up comedy and post-9/11 securitization. Theoretical Criminology, 15(2), 159-177.

Cherney, A., \& Hartley, J. (2015). Community engagement to tackle terrorism and violent extremism: challenges, tensions and pitfalls. Policing and Society: An International Journal of Research and Policy. doi:10.1080/10439463.2015.1089871.

Chon, G. (2015). Abu Hamza sentenced to life in prison. Financial Times, 9 January. http://www.ft.com/cms/s/ 0/e75c7166-9833-11e4-a495-00144feabdc0.html\#axzz3RvdgHexJ. Accessed 8 December 2015.

Choudhury, T. (2012). Impact of counter-terrorism on communities: UK background report. London: Institute for Strategic Dialogue.

Choudhury, T., \& Fenwick, H. (2011). The impact of counter-terrorism measures on Muslim communities. Equality and Human Rights Commission Research Report 72.

Clarke, M. (2005). The contract with Muslims must not be torn up. The Guardian, 25 August. http://www. theguardian.com/politics/2005/aug/26/terrorism.religion. Accessed 8 December 2015.

Coles, M. (2009). Islam, citizenship and education: When hope and history rhyme. Leicester: Islam and Citizenship Education Project.

Credit Suisse. (2014). Global wealth report 2014. Zurich: Credit Suisse AG Research Institute.

Dannreuther, R. (2007). International security: The contemporary agenda. Cambridge: Polity Press.

English, R. (2009). Terrorism: How to respond. Oxford: Oxford University Press.

English, R. (2015). Countering twenty-first century terrorism. Political Insight, 6(3), 22-25.

Enzensberger, H.M. (2006). The radical loser. Sign and Sight, 1 December.

European Commission. (2010). Why socio-economic inequalities increase? Facts and policy responses in Europe. Brussels: European Commission.

Europol. (2015). European union terrorism situation and trend report 2015. The Hague: European Police Office.

Fallaci, O. (2004). La forza della ragione [The force of reason]. Milano: Rizzoli.

Farrar, M. (2015). Why on earth would leftists go out of their way to support cage? Open Democracy, 12 August. http://www.opendemocracy.net/ourkingdom/tom-mills-narzanin-massoumi-david-miller-maxfarrar/why-on-earth-would-leftists-go-out-of. Accessed 7 December 2015. 
Fenton, S., \& Mann, R. (2011). "Our own people": ethnic majority orientations to nation and country. In T. Modood \& J. Salt (Eds.), Global migration, ethnicity and Britishness (pp. 225-247). Basingstoke: Palgrave Macmillan.

Fenwick, H. (2011a). Counter-terror strategies, human rights and the roles of technology. International Review of Law Computers and Technology, 25(3), 107-115.

Fenwick, H. (2011b). Preventive anti-terrorist strategies in the UK and ECHR: control orders, TPIMs and the role of technology. International Review of Law Computers and Technology, 25(3), 129-141.

Fenwick, H. (2016). Responding to the ISIS threat: extending coercive non-trial-based measures in the counter-terrorism and security act 2015. International Review of Law, Computers and Technology. doi: 10.1080/13600869.2016.1145870.

Foucault, M. (1977). Discipline and punish: The birth of the prison. Translated by A. Sheridan. London: Allen Lane.

Fox, J. (2001). Two civilizations and ethnic conflict: Islam and the West. Journal of Peace Research, 38(4), 459-472.

Freedman, J. (2004). Secularism as a barrier to integration? The French dilemma. International Migration, $42(3), 5-25$.

Fukuyama, F. (1989). The end of history? The National Interest, 16(summer), 3-18.

Garcia, B., \& Geva, N. (2016). Security versus liberty in the context of counterterrorism: an experimental approach. Terrorism and Political Violence, 28(1), 30-48.

Garland, D. (2001). The culture of control. Oxford: Oxford University Press.

Gearson, J., \& Rosemont, H. (2015). CONTEST as strategy: reassessing Britain's counterterrorism approach. Studies in Conflict and Terrorism, 38(12), 1038-1064.

Giddens, A. (1991). Modernity and self-identity: Self and society in late modern age. Stanford: Stanford University Press.

Gramsci, A. (1971 [1947]). Selections from the prison notebooks. Translated by Q. Hoare \& G.N. Smith. London: Lawrence and Wishart.

Habeck, M., Carafano, J., Donnelly, T., Hoffman, B., Jones, S., Kagan, F., Kagan, K., Mahnken, T., \& Zimmerman, K. (2015). A global strategy for combating al Qaeda and the Islamic State. Washington: American Enterprise Institute.

Hallsworth, S., \& Lea, J. (2011). Reconstructing Leviathan: Emerging contours of the security state. Theoretical Criminology, 15(2), 141-157.

Hanson, V. (2001). Why the West has won: Carnage and culture from Salamis to Vietnam. London: Faber.

Harari, Y. N. (2014). Sapiens: A brief history of humankind. London: Harvill Secker.

Hassaïne, R., \& Barling, K. (2014). Abu Hamza: Guilty. The fight against radical Islam. Faringdon: Libri Publishing.

Hegghammer, T., \& Nesser, P. (2015). Assessing the Islamic State's commitment to attacking the West. Perspectives on Terrorism, 9(4), 14-30.

Hellyer, H. (2007). British Muslims: past, present and future. The Muslim World, 97(2), 225-258.

Henderson, E., \& Tucker, R. (2001). Clear and present strangers: the clash of civilizations and international conflicts. International Studies Quarterly, 45(2), 317-338.

Herbert, D. (2012). Shifting securities in Northern Ireland: "terror" and the "troubles" in global media and local memory. European Journal of Cultural Studies, 10(3), 343-359.

Herrington, L. (2015a). Incubating extremist terrorism: The UK Islamic fundamentalist movement 1989-2014. University of Warwick: Unpublished PhD Thesis.

Herrington, L. (2015a). British Islamic extremist terrorism: the declining significance of al-Qaeda and Pakistan. International Affairs, 91(1), 17-35.

Hewitt, S. (2008). The British war on terror: Terrorism and counter-terrorism on the home front since 9/11. London: Continuum.

Hickman, M., Thomas, L., Silvestri, S., \& Nickels, H. (2011). 'Suspect communities'? Counter-terrorism policy, the press, and the impact on Irish and Muslim communities in Britain. London: London Metropolitan University.

Hillyard, P. (1993). Suspect community: People's experience of the prevention of terrorism acts in Britain. London: Pluto Press.

Hoffman, B. (2014). The 7/7 London underground bombing: not so homegrown. In B. Hoffman \& F. Reinares (Eds.), The evolution of the global terrorist threat: From 9/11 to Osama Bin Laden's death (pp. 192-223). New York: Columbia University Press.

Holbrook, D. (2014). The al-Qaeda doctrine: The framing and evolution of the leadership's public discourse. New York: Bloomsbury. 
Home Office. (2011). CONTEST: The United Kingdom's strategy for countering terrorism. London: Her Majesty's Stationery Office.

Home Office. (2015a). The National Security Strategy and Strategic Defence and Security Review 2015. London: Her Majesty's Stationery Office.

Home Office. (2015b). Counter-extremism strategy. London: Counter-Extremism Directorate.

Home Office. (2015c). Channel duty guidance: Protecting vulnerable people from being drawn into terrorism. London: Her Majesty's Stationery Office.

Horne, C., \& Bestvater, S. (2016). Assessing the effects of changes in British counterterrorism policy on radical Islamist networks in the UK, 1999-2008. Behavioral Sciences of Terrorism and Political Aggression, 8(2), 87-110.

House of Commons. (2012). Roots of violent radicalisation, nineteenth report of session 2010-12 (vol I). London: Her Majesty's Stationery Office.

Hudson, B. (2007). Diversity, crime and criminal justice. In M. Maguire, R. Morgan, \& R. Reiner (Eds.), The Oxford handbook of criminology (4th ed., pp. 158-175). Oxford: Oxford University Press.

Human Rights Watch. (2010). Without suspicion: Stop and search under the Terrorism Act 2000. New York: Human Rights Watch.

Huntington, S. (1993). The clash of civilizations? Foreign Affairs, 72(3), 22-49.

Huntington, S. (1996). The West unique, not universal. Foreign Affairs, 75(6), 28-46.

Ibrahim, Y. (2007). 9/11 as a new temporal phase for Islam: the narrative and temporal framing of Islam in crisis. Contemporary Islam, 1(1), 37-51.

Ignatieff, M. (2004). The lesser evil: Political ethics in the age of terror. Princeton: Princeton University Press.

Intelligence and Security Committee. (2009). Could 7/7 have been prevented? Review of the intelligence on the London terrorist attacks on 7 July 2005. London: Her Majesty’s Stationery Office.

Kiss, Z., \& Park, A. (2014). National identity: exploring Britishness. In A. Park, C. Bryson, \& J. Curtice (Eds.), British social attitudes: The 31st report (pp. 78-94). London: NatCen Social Research.

Kundnani, A. (2014). The Muslims are coming! Islamophobia, extremism, and the domestic war on terror. London: Verso Books.

Kurzman, C. (2012). Muslim-American terrorism in the decade since 9/11. Durham: Triangle Center on Terrorism and Homeland Security.

LaFree, G., Morris, N., \& Dugan, L. (2010). Cross-national patterns of terrorism: comparing trajectories for total, attributed and fatal attacks, 1970-2006. British Journal of Criminology, 50(4), 622-649.

Lambert, R. (2008). Empowering Salafis and Islamists against al-Qaeda: a London counterterrorism case study. Political Science \& Politics, 41(1), 31-35.

Lambert, R. (2011). Countering al-Qaeda in London: Police and Muslims in partnership. London: Hurst.

Leiken, R. (2005). Europe's angry Muslims. Foreign Affairs, 84(4), 120-135.

Levi, M. (2007). Organized crime and terrorism. In M. Maguire, R. Morgan, \& R. Reiner (Eds.), The Oxford handbook of criminology (4th ed., pp. 771-809). Oxford: Oxford University Press.

Lewis, V., \& Kashyap, R. (2013). Are Muslims a distinctive minority? An empirical analysis of religiosity, social attitudes, and Islam. Journal for the Scientific Study of Religion, 52(3), 617-626.

Lister, C. (2015). A long way from success: assessing the war on the Islamic state. Perspectives on Terrorism, 9(4), 3-13.

Loader, I., \& Walker, N. (2007). Civilizing security. Cambridge: Cambridge University Press.

Lowles, N., \& Mulhall, J. (2013). Gateway to terror: Anjem Choudary and the al-Muhajiroun network. London: Hope Not Hate Publications.

Lynch, O. (2013). British Muslim youth: radicalisation, terrorism and the construction of the "other". Critical Studies on Terrorism, 6(2), 241-261.

Madeley, J. (2003). European liberal democracy and the principle of state religious neutrality. West European Politics, 26(1), 1-22.

Mazrui, A. (2001). Pretender to universalism: Western culture in a globalizing age. Journal of Muslim Minority Affairs, 21(1), 11-24.

Meer, N. (2014a). Integration, extremism and Britain's Muslims. In D. Fieldman \& B. Gidley (Eds.), Integration disadvantage and extremism (pp. 30-34). London: Birbeck University of London.

Meer, N. (2014b). Islamophobia and postcolonialism: continuity, orientalism and Muslim consciousness. Patterns of Prejudice, 48(5), 500-515.

MI5. (2016). Terrorist threat levels. http://www.mi5.gov.uk/home/the-threats/terrorism/threat-levels.html. Accessed 25 February 2015.

Ministry of Defence. (2002). The Strategic Defence Review: A new chapter. London: Her Majesty's Stationery Office. 
Modood, T. (2010). Moderate secularism, religion as identity and respect for religion. The Political Quarterly, $81(1), 4-14$.

Modood, T., \& Salt, J. (2011). Migration, minorities and the nation. In T. Modood \& J. Salt (Eds.), Global migration, ethnicity and Britishness (pp. 3-13). Basingstoke: Palgrave Macmillan.

Mueller, J. (2006). Is there still a terrorist threat? The myth of the omnipresent enemy. Foreign Affairs, 85(5), 2-8.

Murray, A., Mueller-Johnson, K., \& Sherman, L. (2015). Evidence-based policing of U.K. Muslim communities: linking confidence in the police with area vulnerability to violent extremism. International Criminal Justice Review, 25(1), 64-79.

Mythen, G., \& Walklate, S. (2006). Criminology and terrorism: which thesis? Risk society or governmentality? British Journal of Criminology, 46(3), 379-398.

Mythen, G., Walklate, S., \& Khan, F. (2009). "I'm a Muslim, but I'm not a terrorist": victimization, risky identities and the performance of safety. British Journal of Criminology, 49(6), 736-754.

Nesser, P. (2015). Islamist terrorism in Europe: A history. London: Hurst.

Nisbet, R. (1953). The quest for community: A study in the ethics of order and freedom. New York: Oxford University Press.

Noble, G. (2005). The discomfort of strangers: racism, incivility and ontological security in a relaxed and comfortable nation. Journal of Intercultural Studies, 26(1), 107-120.

Norris, P., \& Inglehart, R. (2003). The true clash of civilizations. Foreign Policy, 135, 62-70.

O’Toole, T., Meer, N., DeHanas, D., Jones, S., \& Modood, T. (2015). Governing through Prevent? Regulation and contested practice in state-Muslim engagement. Sociology, 50(1), 160-177.

Osborne, D., \& Gaebler, T. (1992). Reinventing government: How the entrepreneurial spirit is transforming the public sector. Reading: Addison Wesley.

Pantazis, C., \& Pemberton, S. (2009). From the "old" to the "new" suspect community: examining the impacts of recent UK counter-terrorist legislation. British Journal of Criminology, 49(5), 646-666.

Pantucci, R. (2015). We love death as you love life: Britain's suburban terrorists. London: Hurst.

Pew Global Attitudes Project. (2006). The great divide: How Westerners and Muslims view each other. Washington: Pew Research Centre.

Pew Global Attitudes Project. (2011). Common concerns about Islamic extremism: Muslim-Western tensions persist. Washington: Pew Research Centre.

Pew Global Attitudes Project. (2015). Faith in European project reviving. Washington: Pew Research Centre.

Pinker, S. (2011). The better angels of our nature: Why violence has declined. London: Allen Lane.

Poynting, S., \& Mason, V. (2006). "Tolerance, freedom, justice and peace?" Britain, Australia and antiMuslim racism since September 2001. Journal of Intercultural Studies, 27(4), 365-391.

Putnam, R. (2000). Bowling alone: The collapse and revival of community in America. New York: Simon \& Schuster.

Renan, E. (1939). What is a nation? In A. Zimmern (Ed.), Modern political doctrines (pp. 186-205). London: Oxford University Press.

Richards, A. (2012). Characterising the UK terrorist threat: the problem with non-violent ideology as a focus for counter-terrorism and terrorism as the product of "vulnerability". Journal of Terrorism Research, 3(1), $17-26$.

Roberts, A. (2005). The "war on terror" in historical perspective. Survival, 47(2), 101-130.

Roberts, A. (2012). The long peace getting longer. Survival: Global Politics and Strategy, 54(1), 175-184.

Russett, B., Oneal, J., \& Cox, M. (2000). Clash of civilizations, or realism and liberalism déjà vu? Some evidence. Journal of Peace Research, 37(5), 583-608.

Said, E. (2003 [1978]). Orientalism: Western conceptions of the Orient. London: Penguin Books.

Schiermeier, Q. (2015). Terror prediction hits limits. Nature, 517(7535), 419-420.

Schmid, A. (2011). The definition of terrorism. In A. Schmid (Ed.), The Routledge handbook of terrorism research (pp. 39-98). London: Routledge.

Schmid, A. (2014). Violent and non-violent extremism: two sides of the same coin? ICCT Research Paper. The Hague: The International Centre for Counter-Terrorism.

Sentas, V. (2015). Policing the diaspora: Kurdish Londoners, MI5 and the proscription of terrorist organizations in the United Kingdom. British Journal of Criminology. doi:10.1093/bjc/azv094.

Simon, J. (2007). Governing through crime: How the war on crime transformed American democracy and created a culture of fear. New York: Oxford University Press.

Spengler, O. (1927). The decline of the West: Form and actuality. Translated by C. F. Atkinson. New York: Knopf.

Storm, M., Cruickshank, P., \& Lister, T. (2014). Agent Storm: My life inside al-Qaeda and the CIA. New York: Atlantic Monthly. 
Tausch, A. (2015). Estimates on the global threat of Islamic State terrorism in the face of the 2015 Paris and Copenhagen attacks. Middle East Review of International Affairs, 19(1), 37-58.

The Guardian. (2016). Prevent isn't making anyone safer. It is demonising Muslims and damaging the fabric of trust in society. The Guardian, 10 February. http://www.theguardian.com/politics/2016/feb/10/preventisnt-making-anyone-safer-it-is-demonising-muslims-and-damaging-the-fabric-of-trust-in-society. Accessed 20 February 2015.

The Independent. (2015). PREVENT will have a chilling effect on open debate, free speech and political dissent. The Independent, 10 July. http://www.independent.co.uk/voices/letters/prevent-will-have-achilling-effect-on-open-debate-free-speech-and-political-dissent-10381491.html. Accessed 7 December 2015.

The White House. (2002). The national security strategy of the United States of America. Washington: The White House.

Thomas, P. (2012). Responding to the threat of violent extremism - failing to prevent. London: Bloomsbury Academic.

Times Higher Education. (2016). Stop, look, listen: the university's role in counterterrorism - the secularists' view. Times Higher Education, 14 January. http://www.timeshighereducation.com/features/theuniversitys-role-in-counterterrorism-stop-look-and-listen. Accessed 20 February 2015.

Tocci, N. (2009). When and why does the EU act as a normative power in its neighbourhood? In M. Emerson (ed.), Readings in European security (vol 5, pp. 125-134). Brussels: Centre for European Policy Studies.

Toynbee, A. (1974 [1934/1939]). A study of history. Abridgement of vols. I-VI by D.C. Somervell. New York: Oxford University Press.

Turner, B. (2012). Managing religions, citizenship and the liberal paradox. Citizenship Studies, 16(8), 10591072.

Vidino, L. (2010). The new Muslim Brotherhood in the West. New York: Columbia University Press.

Vidino, L. (2015a). Jihadism in Europe. In IEMed Mediterranean yearbook 2015. Barcelona: Institut Europeu de la Mediterrània.

Vidino, L. (2015b). Sharia4: from confrontational activism to militancy. Perspectives on Terrorism, 9(2), 2-16.

Vidino, L., \& Brandon, J. (2012). Countering radicalisation in Europe. London: The International Centre for the Study of Radicalisation and Political Violence.

Vidino, L., \& Hughes, S. (2015). ISIS in America: From retweets to Raqqa. Washington: George Washington University.

Wacquant, L. (2009). Punishing the poor: The neoliberal government of social insecurity. Durham: Duke University Press.

Weber, M. (1946 [1919]). Politics as a vocation. In H. Gerth, \& W. Mills (Eds.), From Max Weber: Essays in sociology (pp. 77-128). New York: Oxford University Press.

York, C. (2015). Islamic State terrorism is serious but we've faced even deadlier threats in the past. Huffington Post UK, 29 November. http://www.huffingtonpost.co.uk/2015/11/28/islamic-state-terrorism-threat_n_ 8670458.html. Accessed 6 December 2015.

YouGov. (2013). British attitude to integration. http://cdn.yougov.com/cumulus_uploads/document/ 4opseuuz4d/YG-Archive-Cam-migrants-integration-results-080513.pdf. Accessed 6 December 2015.

Zedner, L. (2008). Terrorism, the ticking bomb and criminal justice values. Criminal Justice Matters, 73(1), $18-19$.

Zee, M. (2016). Choosing sharia? Multiculturalism, Islamic fundamentalism and British sharia councils. The Hague: Eleven International Publishing.

Zolberg, A., \& Woon, L. (1999). Why Islam is like Spanish: cultural incorporation in Europe and the United States. Politics \& Society, 27(1), 5-38. 